\title{
FORTY-SECOND ANNUAL LIST OF PAPERS
}

READ BEFORE THE AMERICAN MATHEMATICAL SOCIETY AND SUBSEQUENTLY PUBLISHED, INCLUDING REFERENCES TO THE PLACES OF PUBLICATION

Adams, C. R. On non-factorable transformations of double sequences. Read April 14, 1933. Proceedings of the National Academy of Sciences, vol. 19, No. 5, pp. 564-567; May, 1933.

Adams, C. R., and Clarkson, J. A. On definitions of bounded variation for functions of two variables. Read April 15, 1933. Verhandlungen des Internationalen Mathematiker-Kongresses Z ürich 1932, vol. 2, pp. 122-123; 1932.

- On definitions of bounded variation for functions of two variables. Read April 15, 1933. Transactions of this Society, vol. 35, No. 4, pp. 824-854; Oct., 1933.

Adkisson, V. W. Cyclicly connected continuous curves whose complementary domain boundaries are homeomorphic, preserving branch points. Read April 18, 1930. Comptes Rendus des Séances de la Société des Sciences et des Lettres de Varsovie, Classe III, vol. 23, pp. 164-193; 1930.

Agnew, R. P. On Riesz and Cesàro methods of summability. Read Dec. 30, 1931. Transactions of this Society, vol. 35, No. 2, pp. 532-548; April, 1933.

Aitchison, B. Concerning regular accessibility. Read Sept. 9, 1931. Fundamenta Mathematicae, vol. 20, pp. 116-125; 1933.

Albert, A. A. Non-cyclic algebras of degree and exponent four. Read Aug. 31, 1932. Transactions of this Society, vol. 35, No. 1, pp. 112-121; Jan., 1933.

The integers represented by sets of ternary quadratic forms. Read Feb. 28, 1931. American Journal of Mathematics, vol. 55, No. 2, pp. 274-292; April, 1933.

$A$ note on the equivalence of algebras of degree two. Read Feb. 25, 1933. This Bulletin, vol. 39, No. 4, pp. 257-258; April, 1933.

- On primary normal division algebras of degree eight. Read Feb. 25, 1933. This Bulletin, vol. 39, No. 4, pp. 265-272; April, 1933.

$A$ note on the Dickson theorem on universal ternaries. Read April 15, 1933. This Bulletin, vol. 39, No. 8, pp. 585-588; Aug., 1933.

- Normal division algebras over algebraic number fields not of finite degree. Read Oct. 28, 1933. This Bulletin, vol. 39, No. 10, pp. 746-749; Oct., 1933. Cyclic fields of degree eight. Read Feb. 25, 1933. Transactions of this Society, vol. 35, No. 4, pp. 949-964; Oct., 1933.

Albert, $\mathrm{O}$. W. Relations between the projective and metric differential geometries of surfaces. Read Nov. 28, 1931. American Journal of Mathematics, vol. 55, No. 2, pp. 181-196; April, 1933.

Archibald, R. G. Concerning highly composite numbers. Read Dec. 28, 1931. Transactions of the Royal Society of Canada, (3), vol. 26, section 3, pp. 111-118; May, 1932.

Basoco, M. A. On the element of decomposition of a doubly-periodic function of the second kind. Read June 23, 1933. This Bulletin, vol. 39, No. 12, pp. 923-929; Dec., 1933. 
Bateman, H. Some applications of Murphy's theorem. Read Dec. 27, 1932. This Bulletin, vol. 39, No. 2, pp. 118-123; Feb., 1933.

Baten, W. D. Frequency laws for the sum of $n$ variables which are subject each to given frequency laws. Read Nov. 27, 1931. Metron, vol. 10, No. 3, pp. 7591; Sept., 1932.

— Sampling from many parent populations. Read April 8, 1932. Tôhoku Mathematical Journal, vol. 36, No. 2, pp. 206-222; Jan., 1933.

Beckenbach, E. F. Bloch's theorem for minimal surfaces. Read Feb. 25, 1933. This Bulletin, vol. 39, No. 6, pp. 450-456; June, 1933.

Beckenbach, E. F., and Rad6, T. Subharmonic functions and minimal surfaces. Read Dec. 29, 1932. Transactions of this Society, vol. 35, No. 3, pp. 648661; July, 1933.

- Subharmonic functions and surfaces of negative curvature. Read April 14, 1933. Transactions of this Society, vol. 35, No. 3, pp. 662-674; July, 1933.

Bell, E. T. Diophantine equations from algebraic invariants and covariants. Read Aug. 30, 1932. Annals of Mathematics, (2), vol. 34, No. 3, pp. 450-460; July, 1933.

- The Latin square, or cyclic, functions. Read March 18, 1933. Transactions of this Society, vol. 35, No. 3, pp. 734-745; July, 1933.

— Polynomial diophantine systems. Read Oct. 28, 1933. Transactions of this Society, vol. 35, No. 4, pp. 903-914; Oct., 1933.

Bernstein, B. A. Remarks on propositions $* 1 \cdot 1$ and $* 3 \cdot 35$ of Principia Mathematica. Read Sept. 2, 1932. This Bulletin, vol. 39, No. 2, pp. 111-114; Feb., 1933.

- Simplification of the set of four postulates for Boolean algebras in terms of rejection. Read March 18, 1933. This Bulletin, vol. 39, No. 10, pp. 783-787; Oct., 1933.

- On section A of Principia Mathematica. Read March 18, 1933. This Bulletin, vol. 39, No. 10, pp. 788-792; Oct., 1933.

Birkhoff, G. D. Quantum mechanics and asymptotic series. Read June 20, 1933. This Bulletin, vol. 39, No. 10, pp. 681-700; Oct., 1933.

- Aesthetic Measure. Read Nov. 30, 1928. Cambridge, Harvard University Press, 1933. $16+226$ pp.

Birkhoff, G. D., and Trjitzinsky, W. J. Analytic theory of singular difference equations. Read April 9, 1932. Acta Mathematica, vol. 60, Nos. 1-2, pp. $1-89 ; 1933$.

Bliss, G. A. Eliakim Hastings Moore. Read April 14, 1933. The University Record (Chicago), new ser., vol. 19, No. 2, pp. 130-134; April, 1933. This Bulletin, vol 39, No. 11, pp. 831-838; Nov., 1933.

Bliss, G. A., and Hestenes, M. R. Sufficient conditions for a problem of Mayer in the calculus of variations. Read April 8, 1932. Transactions of this Society, vol. 35, No. 1, pp. 305-326; Jan., 1933. Contributions to the Calculus of Variations, 1931-1932, Theses submitted to the Department of Mathematics of the University of Chicago, pp. 295-338; 1933.

Blumberg, H. Note on sets of positive measure. Read April 14, 1923. This Bulletin, vol. 39, No. 6, pp. 369-372; June, 1933.

Blumenthal, L. M., and Garrett, G. A. Characterization of spherical and pseudospherical sets of points. Read Dec. 29, 1932. American Journal of Mathematics, vol. 55, No. 4, pp. 619-640; Oct., 1933. 
Brahana, H. R. Groups $\{S, T\}$ whose commutator subgroups are abelian. Read Aug. 31, 1932. Transactions of this Society, vol. 35, No. 2, pp. 386-396; April, 1933.

_- Prime-power abelian groups generated by a set of conjugates under a special automorphism. Read Aug. 31, 1932. American Journal of Mathematics, vol. 55, No. 4, pp. 553-584; Oct., 1933.

On cubic congruences. Read Oct. 28, 1933. This Bulletin, vol. 39, No. 12, pp. 962-969; Dec., 1933.

Brenke, W. C. On the summability and generalized sum of a series of Legendre polynomials. Read Nov. 26, 1932. This Bulletin, vol. 39, No. 10, pp. 821824; Oct., 1933.

Bullock, R. C. Non-conjugate osculating quadrics of a curve on a surface. Read Dec. 29, 1932. Transactions of this Society, vol. 35, No. 2, pp. 518-531; April, 1933.

Burington, R. S. A classification of quadrics in affine n-space by means of arithmetic invariants. Read April 9, 1932. American Mathematical Monthly, vol. 39, No. 9, pp. 527-532; Nov., 1932.

Bush, L. E. On Young's definition of an algebra. Read Feb. 25, 1933. This Bulletin, vol. 39, No. 2, pp. 142-148; Feb., 1933.

Bushey, J. H., and Shohat, J. A. Sur certains développements en séries des polynomes orthogonaux de Tchebycheff. Read Sept. 8, 1927. Mathematica, vol. 7, pp. 38-50; 1933.

Cairns, S. S. The direction cosines of a p-space in euclidean n-space. Read March 26, 1932. American Mathematical Monthly, vol. 39, No. 9, pp. 518-523; Nov., 1932.

- An axiomatic basis for plane geometry. Read Sept. 9, 1930. Transactions of this Society, vol. 35, No. 1, pp. 234-244; Jan., 1933.

Camp, B. H. The converse of Spearman's two-factor theorem. Read Oct. 29, 1932. Biometrika, vol. 24, Nos. 3-4, pp. 418-427; Nov., 1932.

Campbell, A. D. Pseudo-covariants of an $n$-ic in $m$ variables in a Galois field that consist of terms of this $n$-ic. Read Feb. 25, 1933. This Bulletin, vol. 39, No. 4, pp. 252-256; April, 1933.

- Note on cubic surfaces in the Galois fields of order $2^{n}$. Read Oct. 29, 1932. This Bulletin, vol. 39, No. 6, pp. 406-410; June, 1933.

- Plane quartic curves in the Galois fields of order $2^{n}$. Read Dec. 29, 1932. Tôhoku Mathematical Journal, vol. 37 (First Memorial Volume dedicated to T. Hayashi), pp. 88-93; June, 1933.

Carlitz, L. On a problem in additive arithemetic (II). Read April 11, 1931. Quarterly Journal of Mathematics, Oxford Series, vol. 3, No. 12, pp. 273290; Dec., 1932.

- On Abelian fields. Read Nov. 29, 1930. Transactions of this Society, vol. 35, No. 1, pp. 122-136; Jan., 1933.

- On a theorem of higher reciprocity. Read Dec. 27, 1932. This Bulletin, vol. 39, No. 2, pp. 155-160; Feb., 1933.

- On the representation of a polynomial in a Galois field as the sum of an even number of squares. Read Aug. 31, 1932. Transactions of this Society, vol. 35, No. 2, pp. 397-410; April, 1933. 
Carmichael, R. D. Systems of linear difference equations and expansions in series of exponential functions. Read Aug. 31, 1932. Transactions of this Society, vol. 35, No. 1, pp. 1-28; Jan., 1933.

- Summation of functions of a complex variable Read Aug. 31, 1932. Annals of Mathematics, (2), vol. 34, No. 2, pp. 349-378; April, 1933.

Chittenden, E. W., and Robinson, S. On the reducibility of families of subsets and related properties. Read Nov. 28, 1931. American Journal of Mathematics, vol. 55, No. 2, pp. 197-206; April, 1933.

Clarkson, J. A. On double Riemann-Stieltjes integrals. Read December 27, 1933. This Bulletin, vol. 39, No. 12, pp. 929-936; Dec., 1933. See Adams, C. R.

Clarkson, J. M. Some involutorial line transformations. Read Dec. 29, 1932. This Bulletin, vol. 39, No. 2, pp. 149-154; Feb., 1933.

Involutorial line transformations determined by Cremona plane involutions. Read April 14, 1933. This Bulletin, vol. 39, No. 6, pp. 434-440; June, 1933.

Cohen, L. W. On the minors of absolutely convergent determinants. Read Nov. 28, 1931. Annals of Mathematics, (2), vol. 34, No. 1, pp. 125-129; Jan., 1933.

Coleman, J. B. The Jacobian algorithm for periodic continued fractions as defining a cubic irrationality. Read Dec. 27, 1932. American Journal of Mathematics, vol. 55, No. 4, pp. 585-592; Oct., 1933.

Coral, M. The Euler-Lagrange multiplier rule for double integrals. Read Sept. 9, 1931. Contributions to the Calculus of Variations, 1931-1932, Theses submitted to the Department of Mathematics of the University of Chicago, pp. 63-94; 1933.

Court, N. A. On two intersecting spheres. Read Dec. 29, 1925. American Mathematical Monthly, vol. 40, No. 5, pp. 265-269; May, 1933.

Craig, A. T. Variables correlated in sequence. Read April 8, 1932. This Bulletin, vol. 39, No. 2, pp. 129-136; Feb., 1933.

- On the correlation between certain averages from small samples. Read Dec. 28, 1931. Annals of Mathematical Statistiçs, vol. 4, No. 2, pp. 127-142; May, 1933.

Craig, C. C. On the Tchebychef inequality of Bernstein. Read Sept. 11, 1931. Annals of Mathematical Statistics, vol. 4, No. 2, pp. 94-102; May, 1933.

Craig, H. V. On a covariant differentiation process: Paper II. Read March 25, 1932. This Bulletin, vol. 39, No. 12, pp. 919-922; Dec., 1933.

Currier, A. E. Proof of the fundamental theorems on second-order cross partial derivatives. Read Dec. 27, 1932. Transactions of this Society, vol. 35, No. 1, pp. 245-253; Jan., 1933.

Curry, H. B. A pparent variables from the standpoint of combinatory logic. Read Dec. 31, 1930. Annals of Mathematics, (2), vol. 34, No. 3, pp. 381-404; July, 1933.

Diamond, A. H. The complete existential theory of the Whitehead-Huntington set of postulates for the algebra of logic. Read March 18, 1933. Transactions of this Society, vol. 35, No. 4, pp. 940-948; Oct., 1933.

Dickson, L. E. New results and methods for minima of quadratic forms. Read Dec. 31, 1928. Studies in the Theory of Numbers, Chicago, University of Chicago Press, 1930. 
- Recent progress on Waring's theorem and its generalizations. Read June 23, 1933. This Bulletin, vol. 39, No. 10, pp. 701-727; Oct., 1933.

Dix, C. H. Lattice regions and their application in dynamics. Read Dec. 28, 1931. Tôhoku Mathematical Journal, vol. 36, No. 2, pp. 324-345; Jan., 1933.

Doob, J. L. The boundary values of analytic functions. II. Read March 25 and March 26, 1932. Transactions of this Society, vol. 35, No. 2, pp. 418-451; April, 1933.

Doob, J. L., and Ritt, J. F. Systems of algebraic difference equations. Read June 23, 1933. American Journal of Mathematics, vol. 55, No. 4, pp. 505514; Oct., 1933.

Dorwart, H. L., and Ore, O. Criteria for the irreducibility of polynomials. Read April 3, 1931. Annals of Mathematics, (2), vol. 34, No. 1, pp. 81-94; Jan., 1933.

Douglas, J. A step-polygon of a denumerable infinity of sides which bounds no finite area. Read Dec. 29, 1932. Proceedings of the National Academy of Sciences, vol. 19, No. 1, pp. 188-191; Jan., 1933.

- A Jordan space curve which bounds no finite simply-connected area. Read Feb. 25, 1933. Proceedings of the National Academy of Sciences, vol. 19, No. 2, pp. 269-272; Feb., 1933.

- The Problem of Plateau. Read Oct. 29, 1932. This Bulletin, vol. 39, No. 4, pp. 227-251; April, 1933.

- An analytic closed space curve which bounds no orientable surface of finite area. Read Feb. 25, 1933. Proceedings of the National Academy of Sciences, vol. 19, No. 4, pp. 448-451; April, 1933.

Dressel, F. G. A boundary value problem for the heat equation. Read March 25, 1932. American Journal of Mathematics, vol. 55, No. 4, pp. 641-653; Oct., 1933.

Duncan, D. C. A self-dual septimic possessing seven of each kind of the simple singularities, and autopolar by seven rectangular hyperbolas and a circle. Read March 18, 1933. This Bulletin, vol. 39, No. 8, pp. 589-592; Aug., 1933.

Durfee, W. H. Convergence factors for double series. Read April 8, 1932. This Bulletin, vol. 39, No. 6, pp. 457-464; June, 1933.

Eisenhart, L. P. Spaces admitting complete absolute parallelism. Read Dec. 28, 1932. This Bulletin, vol. 39, No. 4, pp. 217-226; April, 1933.

Emch, A. On an involutorial Cremona transformation in $S_{r}$. Read April 14, 1933. Tôhoku Mathematical Journal, vol. 37 (First Memorial Volume dedicated to T. Hayashi), pp. 100-109; June, 1933.

- Ueber symmetrische Monoide und Kegel. Read April 14, 1933. Commentarii Mathematici Helvetici, vol. 6, No. 2, pp. 133-143; Oct., 1933.

Evans, G. C. Complements of potential theory. Part II. Read Sept. 8, 1931. American Journal of Mathematics, vol. 55, No. 1, pp. 29-49; Jan., 1933.

- Application of Poincarê's sweeping-out process. Read Dec. 29, 1932. Proceedings of the National Academy of Sciences, vol. 19, No. 4, pp. 457461; April, 1933.

Fejér, L. On the infinite sequences arising in the theories of harmonic analysis, of interpolation, and of mechanical quadratures. Read June 21, 1933. This Bulletin, vol. 39, No. 8, pp. 521-534; Aug., 1933. 
Fialkow, A. The geometry of degenerate heat families. Read Oct. 29, 1932. Proceedings of the National Academy of Sciences, vol. 19, No. 5, pp. 543548; May, 1933.

Fischer, C. H. On correlation surfaces of sums with a certain number of random elements in common. Read Dec. 28, 1931. Annals of Mathematical Statistics, vol. 4, No. 2, pp. 103-126; May, 1933.

Foster, A. L. On general Kronecker-(integer)-synthesis of disciplines. Read Aug. 31,1932 . Verhandlungen des Internationalen Mathematiker-Kongresses Zürich 1932, vol. 2, pp. 338-339; 1932.

Foster, M. Note on a special cyclic system. Read March 25, 1932. This Bulletin, vol. 39, No. 6, pp. 375-378; June, 1933.

Franklin, P. The geometric interpretation of some formulas of analytic geometry. Read April 3, 1931. American Mathematical Monthly, vol. 40, No. 3, pp. 143-147; March, 1933.

Frink, O. Jordan measure and Riemann integration. Read Oct. 29, 1932. Annals of Mathematics, (2), vol. 34, No. 3, pp. 518-526; July, 1933.

Garabedian, C. A. Plaque rectangulaire épaisse chargée uniformément dont les deux bords opposés au moins sont appuyés. Read Feb. 25, 1933. Comptes Rendus, vol. 195, No. 26, pp. 1369-1371; Dec. 27, 1932.

Garrett, G. A. See Blumenthal, L. M.

Garver, R. Concerning two square root methods. Read Aug. 31, 1932. Bulletin of the Calcutta Mathematical Society, vol. 24, No. 2, pp. 99-102; June, 1932.

- A square root method and continued fractions. Read Aug. 31, 1932. American Mathematical Monthly, vol. 39, No. 9, pp. 533-535; Nov., 1932.

Concerning the limits of a measure of skewness. Read Sept. 2, 1932. Annals of Mathematical Statistics, vol. 3, No. 4, pp. 358-360; Nov., 1932.

The Gauss-Lucas theorem. Read Nov. 28, 1931. Mathematical Gazette, vol. 16, No. 221, p. 337; Dec., 1932.

- Note on square roots. Read Aug. 31, 1932. Mathematical Gazatte, vol. 16, No. 221, pp. 339-340; Dec., 1932.

- Error expressions for certain continued fractions. Read Aug. 31, 1932. This Bulletin, vol. 39, No. 2, pp. 137-141; Feb., 1933.

- The transformation $y=f^{\prime}(x)$. Read March 18, 1933. Mathematical Gazette, vol. 17, No. 225, p. 256; Oct., 1933.

Gergen, J. J. Convergence criteria for double Fourier series. Read March 25, 1932. Transactions of this Society, vol. 35, No. 1, pp. 29-63; Jan., 1933.

Glenn, O. E. The effect of variations of the force function upon orbits of least action. Read Oct. 26, 1929. Proceedings of the Indiana Academy of Science, vol. 38, pp. 275-277; 1928.

- Astronomical interpretations of a formula in the theory of integral invariants. Read Oct. 26, 1929. Proceedings of the Indiana Academy of Science, vol. 39, pp. 243-246; 1929.

- A theoretical lower limit to the mass of a stable asteroid. Read Sept. 11, 1930. Proceedings of the Indiana Academy of Science, vol. 40, pp. 265-266; 1930.

The mechanics of the stability of a central orbit. Read Sept. 11, 1931. 
Verhandlungen des Internationalen Mathematiker-Kongresses Zürich 1932, vol. 2, p. $281 ; 1932$.

The mechanics of the stability of a central orbit. Read Sept. 11, 1931. Annali della Reale Scuola Normale Superiore di Pisa (Scienze Fisiche e Matematiche), (2), vol. 2, No. 3, pp. 297-308; 1933.

Gordon, W. O. A neighborhood treatment of general topological spaces. Read June 22, 1933. This Bulletin, vol. 39, No. 6, pp. 401-405; June, 1933.

Graves, L. M. On the existence of the absolute minimum in problems of Lagrange. Read Dec. 27, 1932. This Bulletin, vol. 39, No. 2, pp. 101-104; Feb., 1933.

- A transformation of the problem of Lagrange in the calculus of variations. Read Dec. 31, 1930. Transactions of this Society, vol. 35, No. 3, pp. 675682; July, 1933.

Gray, M. C. Mutual impedance of long grounded wires when the conductivity of the earth varies exponentially with depth. Read Nov. 25, 1932. Physics, vol. 4, No. 2, pp. 76-80; Feb., 1933.

Griffin, F. L. The center of population for various continuous distributions of population over areas of various shapes. Read June 18, 1927, and June 2, 1928. Metron, vol. 11, No. 1, pp. 11-15; June, 1933.

Griffin, M. Invariants of Pfaffian systems. Read Dec. 27, 1932. Transactions of this Society, vol. 35, No. 4, pp. 929-939; Oct., 1933.

Griffiths, L. W. Representation by extended polygonal numbers and by generalized polygonal numbers. Read Aug. 29, 1929, and Dec. 30, 1930. American Journal of Mathematics, vol. 55, No. 1, pp. 102-110; Jan., 1933.

Groat, B. F. Generalization in theory of dynamical viscosity. Read Sept. 2, 1932. Brookline, Mass., the author, 1933.15 pp.

Grove, V. G. Contributions to the theory of transformations of nets in a space $S_{n}$. Read April 14, 1933. Transactions of this Society, vol. 35, No. 3, pp. 683-688; July, 1933.

Gut, R. M. Weitere Untersuchungen über die Primidealzerlegung in gewissen relativ-ikosaedrischen Zahlkörpern. Read Feb. 25, 1933. Commentarii Mathematici Helvetici, vol. 6, No. 1, pp. 47-75; July, 1933.

Hall, M. Quadratic residues in factorization. Read March 25, 1932. This Bulletin, vol. 39, No. 10, pp. 758-763; Oct., 1933.

Hancock, H. Integral ideals. The primary theorem. Read Dec. 29, 1926. Foundations of the Theory of Algebraic Numbers, vol. 2, article 14, pp. 24-27; New York, Macmillan, 1932.

Hanson, E. H. A note on compactness. Read Feb. 25, 1933. This Bulletin, vol. 39, No. 6, pp. 397-400; June, 1933.

Hedlund, G. A. Recurrent geodesics on any closed orientable surface of genus one. Read Dec. 29, 1932. Proceedings of the National Academy of Sciences, vol. 18, No. 12, pp. 712-713; Dec., 1932.

Hedrick, E. R. Non-analytic functions of a complex variable. Read Dec. 31, 1931. This Bulletin, vol. 39, No. 2, pp. 75-96; Feb., 1933.

- Tendencies in the logic of mathematics. Read Dec. 28, 1932. Science, new ser., vol. 77, No. 1997, pp. 335-343; April 7, 1933.

Hedrick, E. R., and Whyburn, W. M. An application of the Dedekind cut notion to integration. Read Aug. 31, 1932. American Journal of Mathematics, vol. 55, No. 3, pp. 390-398; July, 1933. 
Hestenes, M. R. Sufficient conditions for the general problem of Mayer with variable end points. Read April 8, 1932. Transactions of this Society, vol. 35, No. 2, pp. 479-490; April, 1933. Contributions to the Calculus of Variations 1931-1932, Theses submitted to the Department of Mathematics of the University of Chicago, pp. 339-360; 1933. See Bliss, G. A.

Hildebrandt, T. H., and Schoenberg, I. J. On linear functional operations and the moment problem for a finite interval in one or several dimensions. Read Aug. 31, 1932. Annals of Mathematics, (2), vol. 34, No. 2, pp. 317-328; April, 1933.

Hille, E., and Tamarkin, J. D. The summation of Fourier series by Hausdorff means. Read April 15, 1933. Verhandlungen des Internationalen Mathematiker-Kongresses Zürich 1932, vol. 2, pp. 131-132; 1932.

- On summability of Fourier series. Read Sept. 9, 1930. Verhandlungen des Internationalen Mathematiker-Kongresses Zürich 1932, vol. 2, pp. 133$134 ; 1932$.

- On the summability of Fourier series. II. Read March 25, 1932. Annals of Mathematics, (2), vol. 34, No. 2, pp. 329-348; April, 1933.

- Questions of relative inclusion in the domain of Hausdorff means. Read April 15, 1933. Proceedings of the National Academy of Sciences, vol. 19, No. 5, pp. 573-577; May, 1933.

- On the summability of Fourier series. III. Read Sept. 9, 1930. Mathematische Annalen, vol. 108, No. 4, pp. 524-577; June, 1933.

- Addition to the paper "On the summability of Fourier series. II." Read March 25, 1932. Annals of Mathematics, (2), vol. 34, No. 3, pp. 602-605; July, 1933.

Hollcroft, T. R. The general web of surfaces and the space involution defined by it. Read Dec. 29, 1932. Verhandlungen des Internationalen MathematikerKongresses Zürich 1932, vol. 2, p. 158; 1932.

- Degenerate algebraic manifolds. Read April 18, 1930. Tôhoku Mathematical Journal, vol. 37 (First Memorial Volume dedicated to T. Hayashi), pp. 179-189; June, 1933.

- The general web of algebraic surfaces of order $n$ and the involution defined by it. Read Dec. 29, 1932. Transactions of this Society, vol. 35, No. 4, pp. 855-868; Oct., 1933.

- Characteristics of multiple curves and their residuals. Read April 14, 1933. This Bulletin, vol. 39, No. 12, pp. 959-961; Dec., 1933.

Huntington, E. V. New sets of independent postulates for the algebra of logic, with special reference to Whitehead and Russell's Principia Mathematica. Read Dec. 28, 1931, Sept. 2, 1932, and Oct. 29, 1932. Transactions of this Society, vol. 35, No. 1, pp. 274-304; Jan., 1933. Boolean algebra, a correction. Transactions of this Society, vol. 35, No. 2, pp. 557-558; April, 1933. A second correction. Transactions of this Society, vol. 35, No. 4, p. 971; Oct., 1933.

Ingraham, M. H. On the reduction of a matrix to its rational canonical form. Read Nov. 25, 1932. This Bulletin, vol. 39, No. 6, pp. 379-382; June, 1933.

Ingram, W. H. Electrical oscillations in a non-uniform transmission line. Read Nov. 29, 1929. University of Washington Publications in Mathematics, vol. 2, No. 1, pp. 17-38; Dec., 1930. 
Jackson, D. Problems of approximation with integral auxiliary conditions. Read Nov. 26, 1932. American Journal of Mathematics, vol. 55, No. 2, pp. 153166; April, 1933.

Series of orthogonal polynomials. Read Aug. 30, 1932. Annals of Mathematics, (2), vol. 34, No. 3, pp. 527-545; July, 1933.

The convergence of some non-linear processes of approximation. Read Dec. 29, 1932. American Journal of Mathematics, vol. 55, No. 4, pp. 515-524; Oct., 1933.

- Certain problems of closest approximation. Read June 21, 1933. This Bulletin, vol. 39, No. 12, pp. 889-906; Dec., 1933.

Jeffery, R. L. Sets of k-extent in n-dimensional space. Read March 25, 1932. Transactions of this Society, vol. 35, No. 3, pp. 629-647; July, 1933.

Jerbert, A. R. Quintuples of curves in four-space. Read Oct. 27, 1928. University of Washington Publications in Mathematics, vol. 2, No. 1, pp. 39-47; Dec., 1930.

Kasner, E. Conformality in connection with functions of two complex variables. Read Sept. 11, 1908. Verhandlungen des Internationalen MathematikerKongresses Zürich 1932, vol. 2, p. 62; 1932.

- Element transformations of space for which normal congruences of curves are invariant. Read April 29, 1916. Verhandlungen des Internationalen Mathematiker-Kongresses Zürich 1932, vol. 2, p. 168; 1932.

- Conformal geometry in the complex domain. Read April 24, 1915. Verhandlungen des Internationalen Mathematiker-Kongresses Zürich 1932, vol. 2, p. $180 ; 1932$.

- Curvature theorems in dynamics. Read Oct. 30, 1909. Verhandlungen des Internationalen Mathematiker-Kongresses Zürich 1932, vol. 2, pp. 180$181 ; 1932$.

- Geometry of the heat equation. Second paper: The three degenerate types of Laplace, Poisson and Helmholtz. Read Dec. 28, 1916. Proceedings of the National Academy of Sciences, vol. 19, No. 2, pp. 257-262; Feb., 1933.

Kempner, A. J. On the shape of polynomial curves. Read Sept. 9, 1927. Tôhoku Mathematical Journal, vol. 37 (First Memorial Volume dedicated to T. Hayashi), pp. 347-362; June, 1933.

Kimball, B. F. The application of Bernoulli polynomials of negative order to differencing. Read Sept. 12, 1930, and March 25, 1932. American Journal of Mathematics, vol. 55, No. 3, pp. 399-416; July, 1933.

Kimball, W. S. The ellipsoidal viscosity distribution. Read Dec. 29, 1932. Philosophical Magazine, (7), vol. 16, No. 103, pp. 1-49; July, 1933.

Knebelman, M. S. A canonical form for a set of vectors. Read June 22, 1933. Proceedings of the National Academy of Sciences, vol. 19, No. 7, pp. 691696; July, 1933.

Korzybski, A. Science and sanity. An introduction to non-aristotelian systems and general semantics. Read Oct. 25, 1930, and Dec. 28, 1931. Lancaster, Pa., Science Press, 1933.

Kusner, J. H. On continuous curves with cyclic connection of higher order. Read March 25, 1932. Comptes Rendus des Séances de la Société des Sciences de Varsovie, Classe III, vol. 25, Nos. 7-9, pp. 71-92; 1933. 
Langer, R. E. An inverse problem in differential equations. Read April 14, 1933 This Bulletin, vol. 39, No. 10, pp. 814-820; Oct., 1933.

$\mathrm{LaPaz}, \mathrm{L}$. Characteristic properties of the euclidean length integral. Read Sept. 11, 1931. American Mathematical Monthly, vol. 39, No. 9, pp. 524-527; Nov., 1932.

Latimer, C. G. On the class numbers of a cyclic field and a sub-field. Read Dec. 27, 1932. This Bulletin, vol. 39, No. 2, pp. 115-118; Feb., 1933.

- On the class number of a cyclic field. Read Dec. 28, 1931. Transactions of this Society, vol. 35, No. 2, pp. 411-417; April, 1933.

Latimer, C. G., and MacDuffee, C. C. A correspondence between classes of ideals and classes of matrices. Read Sept. 9, 1931. Annals of Mathematics, (2), vol. 34, No. 2, pp. 313-316; April, 1933.

Latshaw, V. V. The algebra of self-adjoint boundary-value problems. Read Oct. 31, 1931. This Bulletin, vol. 39, No. 12, pp. 969-978; Dec., 1933.

Lefschetz, S., and Whitehead, J. H. C. On analytical complexes. Read Aug. 31, 1932. Transactions of this Society, vol. 35, No. 2, pp. 510-517; April, 1933.

Lehmer, D. H. Factorization of certain cyclotomic functions. Read Nov. 28, 1931. Annals of Mathematics, (2), vol. 34, No. 3, pp. 461-479; July, 1933.

Lehmer, D. N. On ternary continued fractions. Read Aug. 31, 1932. Tôhoku Mathematical Journal, vol. 37 (First Memorial Volume dedicated to T. Hayashi), pp. 436-445; June, 1933.

- $A$ census of squares of order 4, magic in rows, columns, and diagonals. Read Dec. 2, 1933. This Bulletin, vol. 39, No. 12, pp. 981-982; Dec., 1933.

Lev, J. Effects of linear transformations on the divergence of bounded sequences and functions. Read Dec. 27, 1932. Transactions of this Society, vol. 35, No. 4, pp. 888-896; Oct., 1933.

Levi-Civita, T. Some mathematical aspects of the new mechanics. Read June 20, 1933. This Bulletin, vol. 39, No. 8, pp. 535-563; Aug., 1933.

Lewis, D. C. Infinite systems of ordinary differential equations with applications to certain second-order partial differential equations. Read Dec. 27, 1932. Transactions of this Society, vol. 35, No. 4, pp. 792-823; Oct., 1933.

Littauer, S. B., and Morse, M. A characterization of fields in the calculus of variations. Read Oct. 29, 1932. Proceedings of the National Academy of Sciences, vol. 18, No. 12, pp. 724-730; Dec., 1932.

Lotka, A. J. The growth of mixed populations: two species competing for a common food supply. Read Dec. 29, 1928. Journal of the Washington Academy of Sciences, vol. 22, Nos. 16-17, pp. 461-469; Oct. 19, 1932.

Luther, C. F. Concerning primitive groups of class u. Read Aug. 31, 1932. American Journal of Mathematics, vol. 55, No. 1, pp. 77-101; Jan., 1933. Concerning primitive groups of class $u$; paper II. Read March 18, 1933. American Journal of Mathematics, vol. 55, No. 4, pp. 611-618; Oct., 1933.

McCoy, N. H. On the resultant of a system of forms homogeneous in each of several sets of variables. Read Sept. 9, 1931. Transactions of this Society, vol. 35, No. 1, pp. 215-233; Jan., 1933.

- On complete independence of certain sets of postulates for fields. Read Dec. 29; 1932. This Bulletin, vol. 39, No. 6, pp. 387-391; June, 1933. 
McFarlan, L. H. Sufficient conditions in the problem of Lagrange of the calculus of variations with one variable end point. Read June 21, 1929. University of Washington Publications in Mathematics, vol. 2, No. 1, pp. 49-57; Dec., 1930.

McShane, E. J. Parametrizations of saddle surfaces, with application to the problem of Plateau. Read Oct. 29, 1932. Transactions of this Society, vol. 35, No. 3, pp. 716-733; July, 1933.

MacColl, L. A. On the distributions of the zeros of certain analytic functions. Read Oct. 29, 1932. Proceedings of the National Academy of Sciences, vol. 18, No. 11, pp. 669-671; Nov., 1932.

MacDuffee, C. C. Matrices with elements in a principal ideal ring. Read April 15, 1933. This Bulletin, vol. 39, No. 8, pp. 564-584; Aug., 1933. See Latimer, C. G.

Maier, W. Theorie der s-Funktion. Read Nov. 29, 1930. Journal für Mathematik, vol. 166, No. 2, pp. 101-115; Dec., 1931.

- Aufgaben und Lösungen, 100: Aufgaben zur Integralrechnung. Read April 3, 1931. Jahresbericht der Deutschen Mathematiker Vereinigung, vol. 40, Nos. 6-8, Abteilung 2, p. 47; 1931.

Manning, W. A. The degree and class of multiply transitive groups, III. Read Aug. 30, 1932, and June 19, 1933. Transactions of this Society, vol. 35, No. 3, pp. 585-599; July, 1933.

Marden, M. Further mean-value theorems. Read April 15, 1933. This Bulletin, vol. 39, No. 10, pp. 750-754; Oct., 1933.

Miller, G. A. Groups in which every operator has at most a prime number of conjugates. Read June 19, 1933. Transactions of this Society, vol. 35, No. 4, pp. 897-902; Oct., 1933.

Milne, W. E. On the numerical integration of certain differential equations of the second order. Read June 13, 1931. American Mathematical Monthly, vol. 40, No. 6, pp. 322-327; June-July, 1933.

Montgomery, D. Sections of point sets. Read Nov. 25, 1932. Transactions of this Society, vol. 35, No. 4, pp. 915-928; Oct., 1933.

Moore, C. N. On certain properties of the Fourier constants of $L$ integrable functions of two variables. Read April 15, 1933. Verhandlungen des Internationalen Mathematiker-Kongresses $Z$ ürich 1932, vol. 2, pp. 121-122; 1932.

- On the use of Cesdro means in determining criteria for Fourier constants. Read June 21, 1933. This Bulletin, vol. 39, No. 12, pp. 907-913; Dec., 1933.

Morrey, C. B. A class of representations of manifolds. Part I. Read Oct. 29, 1932. American Journal of Mathematics, vol. 55, No. 4, pp. 683-707; Oct., 1933.

Morse, M. See Littauer, S. B.

Moskovitz, D. Certain irregular non-homogeneous linear difference equations. Read Nov. 25, 1932. American Journal of Mathematics, vol. 55, No. 4, pp. 525-552; Oct., 1933.

Myers, S. B. Sufficient conditions in the problem of the calculus of variations in $n$-space, in parametric form and under general end conditions. Read March 
26, 1932. Transactions of this Society, vol. 35, No. 3, pp. 746-760; July, 1933.

Neikirk, L. I. A class of continuous curves defined by motion which have no tangent lines. Read April 2, 1927. University of Washington Publications in Mathematics, vol. 2, No. 1, pp. 59-63; Dec., 1930.

- A class of totally discontinuous functions. Read June 18, 1927, and June 2, 1928. University of Washington Publications in Mathematics, vol. 2, No. 1, pp. 65-67; Dec., 1930.

Ore, O. Theory of non-commutative polynomials. Read March 25, 1932. Verhandlungen des Internationalen Mathematiker-Kongresses Zürich 1932, vol. 2, pp. 19-20; 1932.

- Theory of non-commutative polynomials. Read March 25, 1932. Annals of Mathematics, (2), vol. 34, No. 3, pp. 480-508; July, 1933.

On a special class of polynomials. Read Feb. 25, 1933. Transactions of this Society, vol. 35, No. 3, pp. 559-584; July, 1933.

- Abstract ideal theory. Read April 14, 1933. This Bulletin, vol. 39, No. 10, pp. 728-745; October, 1933.

- See Dorwart, H. L.

Paley, R. E. A. C. A special integral function. Read June 23, 1933. Transactions of this Society, vol. 35, No. 3, pp. 709-715; July, 1933.

Paley, R. E. A. C., and Wiener, N. Notes on the theory and application of Fourier transforms. I-II. Read Feb. 25, 1933. Transactions of this Society, vol. 35, No. 2, pp. 348-355; April, 1933.

- Notes on the theory and application of Fourier transforms. III, IV, V, VI, VII. Read Oct. 28, 1933. Transactions of this Society, vol. 35, No. 4, pp. 761-791; Oct., 1933.

Pall, G. On sums of squares. Read April 4, 1931. American Mathematical Monthly, vol. 40, No. 1, pp. 10-18; Jan., 1933.

- The structure of the number of representations function in a binary quadratic form. Read Dec. 28, 1931, and Oct. 29, 1932. Transactions of this Society, vol. 35, No. 2, pp. 491-509; April, 1933.

Peek, R. L., Jr. Some new theorems on limits of variation. Read June 22, 1933. This Bulletin, vol. 39, No. 12, pp. 953-959; Dec., 1933.

Peterson, T. S. Linear integral equations of functions of two variables. Read Dec. 29, 1932. This Bulletin, vol. 39, No. 4, pp. 281-288; April, 1933.

- An integral equation with symmetric kernels. Read March 18, 1933. This Bulletin, vol. 39, No. 12, pp. 914-918; Dec., 1933.

Phillips, H. B. Faraday's law as a basis of electromagnetic theory. Read Dec. 29, 1932. Journal of Mathematics and Physics of the Massachusetts Institute of Technology, vol. 12, Nos. 3-4, pp. 259-273; May, 1933.

Price, G. B. On the Strömgren-Wintner natural termination principle. Read Dec. 29, 1932. American Journal of Mathematics, vol. 55, No. 2, pp. 303-308; April, 1933.

Purcell, E. J. Involutorial space Cremona transformations determined by nonlinear null reciprocities. Read Sept. 2, 1932. American Journal of Mathematics, vol. 55, No. 3, pp. 381-389; July, 1933. 
Rad6, T. An iterative process in the problem of Plateau. Read Dec. 29, 1932. Transactions of this Society, vol. 35, No. 4, pp. 869-887; Oct., 1933. See Beckenbach, E. F.

Rainville, E. D. On the representation of numbers modulo $m$. Read March 18, 1933. This Bulletin, vol. 39, No. 6, pp. 383-385; June, 1933.

Raudenbush, H. W. Differential fields and ideals of differential forms. Read Aug. 31, 1932. Annals of Mathematics, (2), vol. 34, No. 3, pp. 509-517; July, 1933.

Reynolds, J. B. Inextensible chains on fixed plane curves. Read Dec. 27, 1929. Proceedings of the Pennsylvania Academy of Science, vol. 7, pp. 92-98; 1933.

Rider, P. R. On the distribution of the correlation coefficient in small samples. Read Dec. 31, 1930, and Sept. 11, 1931. Biometrika, vol. 24, Nos. 3-4, pp. 382-403; Nov., 1932.

Ritt, J. F. Integral functions obtained by compounding polynomials. Read April 14, 1933. This Bulletin, vol. 39, No. 8, pp. 627-632; Aug., 1933.

- See Doob, J. L.

Robertson, H. P. Relativistic cosmology. Read Sept. 2,1932. Reviews of Modern Physics, vol. 5, No. 1, pp. 62-90; Jan., 1933.

Robinson, S. Covering theorems in general topology. Read Sept. 11, 1931. American Journal of Mathematics, vol. 55, No. 3, pp. 421-436; July, 1933.

- Axiom C of Hausdorff and the property of Borel-Lebesgue. Read Oct. 29, 1932. This Bulletin, vol. 39, No. 8, pp. 595-600; Aug., 1933.

- See Chittenden, E. W.

Ross, A. E. On representation of integers by quadratic forms. Read Nov. 30, 1929, April 19, 1930, and Aug. 31, 1932. Proceedings of the National Academy of Sciences, vol. 18, No. 9, pp. 600-608; Sept., 1932.

- On representation of integers by indefinite ternary quadratic forms of quadratfrei determinant. Read Nov. 30, 1929. American Journal of Mathematics, vol. 55, No. 2, pp. 293-302; April, 1933.

- On criteria for universality of ternary quadratic forms. Read Aug. 31, 1932. Quarterly Journal of Mathematics, Oxford Series, vol. 4, No. 14, pp. 147158; June, 1933.

Roth, W. E. On the equation $P(A, X)=0$ in matrices. Read Nov. 30, 1928, and Sept. 9, 1931. Transactions of this Society, vol. 35, No. 3, pp. 689-708; July, 1933.

Rutledge, G. A reliable method of obtaining the derivative function from smoothed data of observation. Read March 25, 1932. Physical Review, (2), vol. 40, No. 2, pp. 262-268; April, 1932.

Rutt, N. E. Concurrence and uncountability. Read Feb. 25, 1933. This Bulletin, vol. 39, No. 4, pp. 295-302; April, 1933.

- Prime ends and order. Read Feb. 25, 1933. Annals of Mathematics, (2), vol. 34, No. 3, pp. 415-440; July, 1933.

Saks, S. On some functionals. Read Oct. 29, 1932. Transactions of this Society, vol. 35, No. 2, pp. 549-556; April, 1933.

- Addition to the note on some functionals. Read April 14, 1933. Transactions of this Society, vol. 35, No. 4, pp. 965-970; Oct., 1933.

Scherberg, M. G. The degree of convergence of a series of Bessel functions. Read 
Sept. 11, 1931. Transactions of this Society, vol. 35, No. 1, pp. 172-183; Jan., 1933.

Schoenberg, I. J. Convex domains and linear combinations of continuous functions. Read April 14, 1933. This Bulletin, vol. 39, No. 4, pp. 273-280; April, 1933.

- On finite-rowed systems of linear inequalities in infinitely many variables. II. Read Aug. 31, 1932. Transactions of this Society, vol. 35, No. 2, pp. 452-478; April, 1933. See Hildebrandt, T. H.

Sheffer, I. M. The polynomial solutions of linear differential equations; expansions. Read Dec. 27, 1929. Transactions of this Society, vol. 35, No. 1, pp. 184-214; Jan., 1933.

Sherman, J. On the numerators of the convergents of the Stieltjes continued fractions. Read March 26, 1932. Transactions of this Society, vol. 35, No. 1, pp. 64-87; Jan., 1933.

Shohat, J. A. On interpolation. Read Oct. 25, 1930, and Oct. 31, 1931. Annals of Mathematics, (2), vol. 34, No. 1, pp. 130-146; Jan., 1933.

- On the continued fractions associated with, and corresponding to, the integral $\int_{a}^{b} \frac{p(y)}{x-y} d y$. Read Dec. 29, 1932. American Journal of Mathematics, vol. 55, No. 2, pp. 218-230; April, 1933.

See Bushey, J. H.

Shover, G. Class number in a linear associative algebra. Read Nov. 28, 1931. This Bulletin, vol. 39, No. 8, pp. 610-614; Aug., 1933.

Singer, J. Three-dimensional manifolds and their Heegaard diagrams. Read Oct. 29, 1932. Transactions of this Society, vol. 35, No. 1, pp. 88-111; Jan., 1933.

Sinkov, A. Families of groups generated by two operators of the same order. Read March 25, 1932. Transactions of this Society, vol. 35, No. 2, pp. 372-385; April, 1933.

Smith, A. H. On the summability of derived series of the Fourier-Lebesgue type. Read Dec. 27, 1932. Quarterly Journal of Mathematics, Oxford Series, vol. 4, No. 14, pp. 93-106; June, 1933.

Smith, P. A. The topology of involutions. Read Feb. 25, 1933. Proceedings of the National Academy of Sciences, vol. 19, No. 6, pp. 612-618; June, 1933.

Snyder, V. On a series of Cremona involutions defined by a pencil of ruled surfaces. Read Dec. 29, 1932. Verhandlungen des Internationalen Mathematiker-Kongresses Zürich 1932, vol. 2, p. 160; 1932.

- On a series of involutorial Cremona transformations of space defined by a pencil of ruled surfaces. Read Dec. 29, 1932. Transactions of this Society, vol. 35, No. 2, pp. 341-347; April, 1933.

Sokolnikoff, E. S. (Elizabeth Stafford). Matrices conjugate to a given matrix with respect to its minimum equation. Read April 19, 1930. American Journal of Mathematics, vol. 55, No. 2, pp. 167-180; April, 1933.

Stone, M. H. Linear transformations in Hilbert space and their applications to analysis. Read Oct. 27, 1928. American Mathematical Society Colloquium Publications, vol. $15 ; 1932.8+622$ pp.

Stouffer, E. B. On the projective differential geometry of developable surfaces. 
Read Dec. 1, 1928. Verhandlungen des Internationalen MathematikerKongresses $Z$ ürich 1932, vol. 2, pp. 170-171; 1932.

Sullivan, M. On the derivatives of Newtonian and logarithmic potentials near the acting masses. Read Oct. 31, 1931. Transactions of this Society, vol. 35, No. 1, pp. 137-171; Jan., 1933.

Synge, J. L. Thermostatic control. Read Dec. 28, 1931. American Mathematical Monthly, vol. 40, No. 4, pp. 202-216; April, 1933.

Tamarkin, J. D. See Hille, E.

Thomas, J. M. Regular differential systems of the first order. Read March 25, 1932. Proceedings of the National Academy of Sciences, vol. 19, No. 4, pp. 451-453; April, 1933.

Pfaffian systems of species one. Read Dec. 30, 1931. Transactions of this Society, vol. 35, No. 2, pp. 356-371; April, 1933.

Thompson, W. R. On the possible forms of discriminants of algebraic fields. II. Read Dec. 27, 1929. American Journal of Mathematics, vol. 55, No. 1, pp. 111-118; Jan., 1933.

Tolman, R. C. Thermodynamics and relativity. Read Dec. 29, 1932. This Bulletin, vol. 39, No. 2, pp. 49-74; Feb., 1933. Science, new ser., vol. 77, Nos. 1995-1996, pp. 291-298, 313-317; March 24 and March 31, 1933.

Trjitzinsky, W. J. The general case of integro-q-difference equations. Read Dec. 27, 1932. Proceedings of the National Academy of Sciences, vol. 18, No. 12, pp. 713-719; Dec. 1932.

- $A$ property of indefinitely differentiable classes. Read Oct. 29, 1932. Proceedings of the National Academy of Sciences, vol. 18, No. 12, pp. 719722; Dec., 1932.

- The general case of non-homogeneous linear differential equations. Read June 23, 1933. Proceedings of the National Academy of Sciences, vol. 19, No. 7, pp. 687-690; July, 1933.

- Analytic theory of linear $q$-difference equations. Read Oct. 29, 1932. Acta Mathematica, vol. 61, Nos. 1-2, pp. 1-38; 1933.

- See Birkhoff, G. D.

Veblen, O. Geometry of two-component spinors. Read April 14, 1933. Proceedings of the National Academy of Sciences, vol. 19, No. 4, pp. 462-474; April, 1933.

- Geometry of four-component spinors. Read April 14, 1933. Proceedings of the National Academy of Sciences, vol. 19, No. 5, pp. 503-517; May, 1933.

Wadsworth, G. P. Systems of three linear partial differential equations of the third order. Read Aug. 31, 1932. Journal of Mathematics and Physics of the Massachusetts Institute of Technology, vol. 11, Nos. 3-4, pp. 255-272; Sept.-Dec., 1932.

Wall, $\mathrm{H}$. S. On continued fractions which represent meromorphic functions. Read April 15, 1933. This Bulletin, vol. 39, No. 12, pp. 946-952; Dec., 1933.

Walsh, J. L. Note on the location of the critical points of Green's function. Read June 23, 1933. This Bulletin, vol. 39, No. 10, pp. 775-782; Oct., 1933.

Ward, M. The cancellation law in the theory of congruences to a double modulus. Read Aug. 31, 1932. Transactions of this Society, vol. 35, No. 1, pp. 254260; Jan., 1933. 
- The arithmetical theory of linear recurring series. Read Aug. 31, 1932. Transactions of this Society, vol. 35, No. 3, pp. 600-628; July, 1933.

Whitehead, J. H. C. See Lefschetz, S.

Whitney, H. A characterization of the closed 2-cell. Read Oct. 31, 1931. Transactions of this Society, vol. 35, No. 1, pp. 261-273; Jan., 1933.

- A set of topological invariants for graphs. Read Dec. 28, 1931. American Journal of Mathematics, vol. 55, No. 2, pp. 231-235; April, 1933.

- On the classification of graphs. Read Dec. 28, 1931. American Journal of Mathematics, vol. 55, No. 2, pp. 236-244; April, 1933.

2-isomorphic graphs. Read Sept. 2, 1932. American Journal of Mathematics, vol. 55, No. 2, pp. 245-254; April, 1933.

- Regular families of curves. Read March 25, 1932. Annals of Mathematics, (2), vol. 34, No. 2, pp. 244-270; April, 1933.

Characteristic functions and the algebra of logic. Read Dec. 28, 1931. Annals of Mathematics, (2), vol. 34, No. 3, pp. 405-414; July, 1933.

Whyburn, G. T. Characterizations of certain curves by continuous functions defined upon them. Read Dec. 29, 1932. American Journal of Mathematics, vol. 55, No. 1, pp. 131-134; Jan., 1933.

- On the existence of totally imperfect and punctiform connected subsets in a given continuum. Read Dec. 29, 1932. American Journal of Mathematics, vol. 55, No. 1, pp. 146-152; Jan., 1933.

- Sets of local separating points of a continuum. Read Feb. 25, 1933. This Bulletin, vol. 39, No. 2, pp. 97-100; Feb., 1933.

- Decompositions of continua by means of local separating points. Read April 14, 1933. American Journal of Mathematics, vol. 55, No. 3, pp. 437-457; July, 1933.

Concerning S-regions in locally connected continua. Read Sept. 11, 1931. Fundamenta Mathematicae, vol. 20, pp. 131-139; 1933.

Whyburn, W. M. See Hedrick, E. R.

Wiener, N. See Paley, R. E. A. C.

Wiener, N., and Young, R. C. The total variation of $g(x+h)-g(x)$. Read Oct. 29,1932 . Transactions of this Society, vol. 35 , No. 1, pp. 327-340; Jan., 1933.

Wilder, R. L. On the linking of Jordan continua in $E_{n}$ by $(n-2)$-cycles. Read Nov. 28, 1931. Annals of Mathematics, (2), vol. 34, No. 3, pp. 441-449; July, 1933.

Wilks, S. S. Moments and distributions of estimates of population parameters from fragmentary samples. Read March 25, 1932. Annals of Mathematical Statistics, vol. 3, No. 3, pp. 163-195; Aug., 1932.

- On the sampling distribution of the multiple correlation coefficient. Read Dec. 27, 1932. Annals of Mathematical Statistics, vol. 3, No. 3, pp. 196203; Aug., 1932.

Certain generalizations in the analysis of variance. Read March 26, 1932. Biometrika, vol. 24, Nos. 3-4, pp. 471-494; Nov., 1932.

Williams, A. R. Analogs of the Steiner surface and their double curves. Read March 18, 1933. This Bulletin, vol. 39, No. 8, pp. 621-626; Aug., 1933.

Wilson, W. A. On unicoherency about a simple closed curve. Read Oct. 29, 1932. American Journal of Mathematics, vol. 55, No. 1, pp. 135-145; Jan., 1933. 
- A separation theorem. Read Feb. 25, 1933. This Bulletin, vol. 39, No. 6, pp. 440-442; June, 1933.

Winger, R. M. On certain projective trochoids. Read June 13, 1931. American Mathematical Monthly, vol. 39, No. 10, pp. 578-589; Dec., 1932.

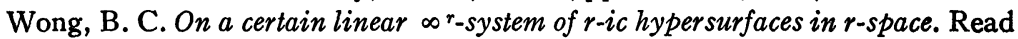
June 21, 1929. American Journal of Mathematics, vol. 55, No. 3, pp. 376380; July, 1933.

Young, R. C. See Wiener, N.

Zippin, L. Independent arcs of a continuous curve. Read March 25, 1932. Annals of Mathematics, (2), vol. 34, No. 1, pp. 95-113; Jan., 1933.

- $A$ characterization of the closed 2-cell. Read Oct. 29, 1932. American Journal of Mathematics, vol. 55, No. 2, pp. 207-217; April, 1933.

On continuous curves irreducible about subsets. Read March 25, 1932. Fundamenta Mathematicae, vol. 20, pp. 197-205; 1933. 